\title{
A MODEL OF EDUCATION FOR WOMEN \\ (A Case Study in Madrasah Muallimat PUI Majalengka - West Java)
}

\author{
Eti Nurhayati \\ IAIN Syekh Nurjati Cirebon \\ email: etinoorhayatie09@gmail.com
}

\begin{abstract}
This study was aimed to describe a model of education for women in Madrasah Muallimat PUI which had unique and specific characteristics, and it is still maintained until now. It is a special education for Muslimah, aiming to make cadres of educators who are regarded as a noble profession for women. The study used a qualitative approach and the data were collected through literature, documentation, in-depth interviews, and participant observation. The findings showed that: (1) The education in PUI's perspective: viewing the importance of education for all human beings, integrating the science and religion, education skills, entrepreneurship, faith, noble morality, and innovative skills; (2) The model of education for women in Madrasah Muallimat included: looking at the importance of educated women, learning science and religion, being fluent in reading the Quran, mastering the Arabic language, being able to read the Kitab as a source of religious instruction, having personality as a true Muslimah who is skilled at the field of women to settle down provision, being eloquent, being able to lead the community, being spirited educators and becoming educators for families and communities, as well as being noble.
\end{abstract}

\section{Keywords: Education for women, Madrasah Muallimat, PUI}

\section{MODEL PENDIDIKAN UNTUK PEREMPUAN (Studi Kasus di Madrasah Muallimat PUI Majalengka - Jawa Barat)}

\begin{abstract}
Abstrak: Studi ini ingin mendeskripsikan model pendidikan di Madrasah Muallimat PUI yang memiliki karakteristik unik dan spesifik, dan masih dipertahankan sampai sekarang, merupakan pendidikan khusus untuk muslimah, bertujuan mencetak kader pendidik yang dipandang sebagai sebuah profesi mulia untuk perempuan. Studi ini menggunakan pendekatan kualitatif dengan teknik pengumpulan data: studi pustaka, dokumentasi, wawancara mendalam, dan observasi partisipasi. Hasil penelitian ini menyimpulkan: (1) Pendidikan dalam perspektif PUI: memandang pentingnya pendidikan bagi semua manusia, mengintegrasikan pengetahuan umum dan agama, pendidikan keterampilan, wirausaha, keimanan, akhlaq mulia, dan inovatif; (2) Model pendidikan di Madrasah Muallimat adalah: memandang pentingnya perempuan berpendidikan, mempelajari ilmu pengetahuan umum dan agama, fasih membaca al-Qur'an, menguasai bahasa Arab, mampu membaca kitab berbahasa Arab, berkepribadian muslimah yang terampil, pandai berpidato, mampu memimpin masyarakat, berjiwa pendidik dan menjadi pendidik bagi keluarga dan masyarakat, serta berakhlaq mulia.
\end{abstract}

Kata Kunci: Pendidikan untuk perempuan, Madrasah Muallimat, PUI

\section{INTRODUCTION}

"Persatuan Ummat Islam" (PUI) is one of the Islamic organizations in West Java that was initiated by K.H. Abdul Halim and K.H. Ahmad Sanusi, established in more than a century ago, which was concerned with education. In the struggle since the Dutch colonial era, PUI had been actively providing education for the people of Indonesia who was left behind in various aspects, such as religion, education, social, economic, and political aspects, as a result of Dutch colonialism.

Education is the most important factor for human life. Indonesia was colonized because the peopledid not have adequate education. People who were not educated were not only incompetence to fightagainst the colonialism, but also did not understand that the colonizer had 
paralyzed the whole aspect to rise up and to be independent, and it also damaged the sensitivity of their pride as a free society. Therefore, it was essential that the colonialism in the world should be abolished because it did not comply with the principles of humanity and justice. K.H Abdul Halim believed that the most significant effort to fight the colonizer was by education. Many countries rose from underdevelopment and imprive their quality of life with the equitable access to educational efforts. "PUI was born as the initiative against the colonialism to provide people by education" (Suradinata, 1982:21).

Education is something that is very important and necessary to achieve the ideals of peace, freedom, and social justice. Education plays an important role in human development, for the personal development of each individual as well as the quality of social life which is more harmonious, and to reduce proverty, ignorance, oppression, and war, as confirmed by Dellors:

In confronting the many challenges that the future holds in store, humankind sees in education an indispensable asset in its attempt to attain the ideals of peace, freedom, and social justice. ...Education has a fundamental role to play in personal and social development. ...Education as a miracle cure or magic formula opening the door to a world in which all ideals will be attained, but as one of the principal means available to foster a deeper and mor harmonious form of human development and thereby to reduce poverty, exclusion, ignorance, oppression, and war (Dellors, 1998:13).

The resistance against colonialismwas done through the educational struggle because it was not only the absence of physical material capital to bear weapons and lack-skills in using weapons, but also that education was very helpful to prepare the fighting spirit, awakening a sense of nationalism, the motivation to rise up. This should be done through educational activities. The importance of education to face colonialism had been reminded by Allah in His word: "And it is not for the believers to go forth (to battle) at once. For there should separate from every division of them a group (remaining) to obtain understanding in the religion and warn their people when they return to them that they might be cautious." (QS. At-Tawbah [9]:122). Therefore, the concern of PUI in the sector of education was a strategic decision.

Education is the crucial process in preparing for the future. The fate of individuals is on each person's preparation for occupation or larger lifetime careers. The present educational disadvantage of women highlights some problems: (1) they have chosen not to strive for such positions, (2) they have been denied equal access and opportunity for education, (3) the culture that an educational institution project is out of date, and (4) training women for a world where occupational and family life are still segregated by sex-roles rather than permeable to crossover.

Madrasah Mualimat is one of the educational institutions of PUI, which was established on April 5, 1961 in Majalengka, and it still retains the characteristics of the educational model of PUI as idealized by its founder, K.H. Abdul Halim.

The education of Madrasah Mualimat PUI in Majalengka became the object of this study because it had the specifications, especially in the view of the position of women who were more moderate and proportional, namely that women should be developed, being achievers and knowledgeable as that reached by men, without forgetting the nature as women who hadmuslimah personality as being noble and skilled at doing domestic work and in the community, working hand in hand with men, being able to practice science, enlightening and education to families and communities, being sensitive and able to make changes for the betterment of society.

Based on that background and reasons for the importance this research, the problem can be formulated as follows: (1) What is the concept of education according to PUI perspective? (2) What kind of educational model for women is practised in Madrasah Mualimat PUI Majalengka?

\section{METHOD}

This study used "a qualitative method" (Neuman, 1997) and the data were collected using interviews, documentary studies, and the participant observation. The interviewtechnique was more effective than the written questionnaires because the researcher herself is the research 
instrument (human instrument) in qualitative research, as Guba (1990) says, that is capable of grasping and evaluating the meaning of that differential interaction. Therefore, this research does not quantity the result of answers by using numbers, but using words.

The main source of the interview is Chalid Fadhullah (the third generation of the Founder of PUI), Yati Rohyati (the Head of Madrasah Mualimat), Uum Umayah (the Senior Teacher), etc. The documents studied were thehistory of Madrasah Muallimat and related general literature. An effort to improve the quality of the qualitative research was by using triangulation. Triangulation was done by checking the data by the other data. The data derived from the interviews crosschecked with the data from the observation and secondary data. In other words, the triangulation was used to obtain the certainty of data or to obtain a more complete illustration of the data and information.

From the interview with Chalid Fadhullah, the following data were obtained: the history of PUI, KH Abdul Halim's struggle in managing the PUI, the struggle to realize the ideals in the field of dakwah and education by establishing many educational institutions, including Madrasah Muallimat which aimed to promote women's education. The interview with Uum Umayyah resulted in the following data: the history and development of Madrasah Muallimat, sciences taught in the past and at present. The interview with Yati Rohyati resulted in the data on the development of Madrasah Muallimat that has been led for 15 years and some missions that were still maintained as the mandate of PUI, such as: the skills of women subjects, organization, leadership, and especially psychology and pedagogy which were still taught, although now in the form of public schools (Madrasah Aliyah Puteri) not a teaching education school (Madrasah Muallimat) anymore.

From the references from Moh Musa Suradinata and Toto Syatori, the following data were obtained: the history of PUI, K.H. Abdul Halim's struggle in the field of dakwah and education, and educational institutions of PUI. Other references were used to strengthen the discussion about the importance of education for women.
This research would be useful to theorists of education for: (1) enriching the information that the educational model developed in the country is quite a lot, varied, unique, has its strengths and weaknesses, (2) being used as a reference in building educational theory, especially Islamic education for women, (3) being used as a comparison from one to another, so it would be useful to draw generalization of educational models which are varied and unique, (4) being used to criticize the educational models that exist in theory, (5) being a bridge between the paradigm of the theoretical into the practical education which is in fact in the field, (6) formulating a model of Islamic education that is ideal for women based varied models of education by adopting, criticizing, elaborating, or innovating.

This research would be useful to the practitioners of education for: (1) enriching the knowledge of the educational model, not just the educational practices that have been experienced and practiced as an educator, (2) being a valuable input to adopt a model that is expected to improve education already practiced for a long time, (3) raising the critical attitude to be able to identify the strengths and weaknesses of the educational model, (4) being able to find the limiting factors of the educational model for the advancement of educational practice in the field.

\section{FINDINGS AND DISCUSSIONS Education in Perspective of PUI}

First, PUI viewed that education was very important and fundamental for human beings. This view had been attached to both founders of PUI, K.H. Abdul Halim and K.H. Ahmad Sanusi, who had seen from their thinking that the most prominent was thinking about education.

Young Halim had been a student of the famous Islamic thinker Sheikh Thantawi Jauhari, the author of Tafsir Al-Jawahir and Qur'an walUlumil Asyriyah which was once banned by the Dutch to enter in Indonesia because the influence of this book could trigger Muslim's spirit of nationalism in Indonesia. During his study in Mecca, Halim used to communicate with young people from other countries that were colonized by European nations, and used to read plenty of reading books by Jamaluddin Al-Afghani and Moh Abduh (Nasehuddin, 2004:36). 
Some views of K.H. Abdul Halim about the urgency of education: (a) education is a basic capital to expel colonialism. According to him, the nation was colonized because of the low education and the lack of education resulted in not knowing how to fight against colonizers; (b) education is seen to create a sense of nationalism and patriotism which is the capital to repel colonizers; (c) education could improve the quality of life that allowed to have the strength to fight against the colonizers; (d) education could open awareness that freedom was a human right, and therefore the occupation should be eliminated from the earth because it did not comply with humanity and justice; (e) people educated in the quality of life got in touch more with people and with their God; (f) education is a provision to children in order to have better life than their parents (Interview with Chalid Fadhullah, on September, 5, 2014), as confirmed by Dellorsas follows:

The children and young people who will take over from today's generation of adults, the latter being all too inclined to concentrate on their own problems. Education is also an expression of affection for children and young people, whom we need to welcome into society, unreservedly offering them the place that in theirs by right therein - a place in the education system, to be sure, but also in the family, the local community, and the nation. This elementary duty needs to be constantly brought to mind, so that greater attention is paid to it, even when choosing between political, economic, and financial options. In the words of a poet: "The children is father of the Man" (Delors, 1998:13-14).

Education is an important factor that sustains the human life. It is not too old to be educated. There is always a place for getting further education. Nothing word of regret to earn education. There is no wrong place to visit aside schools and educational institutions. No time to spare which is more useful except for education. Finally, there is no gender requirement to earn education.

Education which is able to educate the nation is education which does not make any discrimination. Both women and men have the same right to obtain education. Education has two major purposes. It shapes and continues the culture itself by creating and passing on knowledge. At the same time it forms the personality of the students who pass under its influence. Educational institutions give them information, a sense of competence, and standards of judgment that they will use at work or in the rest of their lives. The final purpose of education is to keep human beings and society functioning as well as they possibly can within the limitations of present resources. Educational institutions should not mislead students by rewarding them for behavior that is unrelated to the real of life.

Since the existence of Islam in the world, God has emphasized the importance of education for humans. According to Nurmila on her research (2009:175):

Islam emphasizes the importance of education both for men and women. Islam also tries to elevate women's position into equal position with men. However, the strong influence of patriarchal culture on Muslims' understanding of the Qur'an. For example, like many other people in patriarchal culture, many Muslims still believe that women are subordinate to men or second class. This belief is definitely contradictory with the spirit of Islamic teaching, which aims to improve the position of women.

The first revelation that Allah revealed to Muhammad that marked his prophetic treatise is the command for the educated, as the word of Allah: "Recite in the name of your Lord who created. Created man from a clinging substance. Recite, and your Lord is the most Generous. Who taught by the pen. Taught man that which he knew not" (QS. Al-Alaq [96]: 1-5).

Based on that word of Allah, man is demanded to do lifelong learning. The lifelong learning process occurs in an integrated manner, involving all aspects of life.There is an integration between learning, living, and working, they cannot be separated, but they occur together.

Second, education should be an integral part between science and religion. K.H. Abdul Halim 
expects the students become knowledgeable in religious knowledge in general knowledge. Generally in that time, the religious figures in Majalengka still forbade people to study science.

The educational concept of K.H. Abdul Halim and K.H. Ahmad Sanusi is much influenced by the ideas of renewal of Jamaluddin al-Afghani, Mohammad Abduh, and the educational model Rabindranat Tagore. In addition, K.H. Abdul Halimwas also inspired by two educational institutions in Saudi Arabia, namely in the Bab el-Salam and Jeddah (Suradinata, 1982:43). The concept of education which was idealized by Abduh is anintegration of religion with science. The purpose of integrating both sciences are to produce experts in science who has a strong religious foundation, or religious experts who have a broad general knowledge.

The educational concept of K.H. Abdul Halim that have an interest in the mundane and the spiritual is the characteristic of his institutions, as the word of Allah: "But seek, through that which Allah has given you, the home of the Hereafter; and do not forget your share of the world. And doo good as Allah has done good to you. And desire not corruption in the land. Indeed, Allah does not like corrupters" (QS. Al-Qasas [28]:77).

K.H. Abdul Halim did not want a Muslim or muslimah only has the interest in spiritual life purely by ignoring the life business, and instead he was also opposed to the attitude of people who only put the life business by leaving the spiritual life. The education concept idealized by K.H. Abdul Halim is based on a consideration after seeing the reality in schools established by government at that time. They did not teach religion lessons under the reason of neutral religion. This policy would cause the students not to know about their religion or belief.

The education which was founded by KH. Abdul Halim used two systems, namely the system of madrasah and that of general schools, such as Volk School until grade three, followed HollandsInlandse School (HIS) or Islam Onderwijs Institute through the sixth grade (Suradinata, 1982:54). The pattern of education in Madrasah Muallimin and Muallimat (having the same grade as Hogere Burger School or HBS) used Arabic as the language of instruction at grade one. Dutch and English began to be taught in the third grade. French and German were taught in grades four and five as elective subjects.

K.H. Abdul Halim's educational concept that integrates religion and science is desired in accordance with the Islamic concept. Basically the "science" in Islam is one, that is, "knowledge of Allah", as Malik Fajar (1998: 18) quotes from the Mahdi Ghulsyani in "the Holy Quran and the Science of Nature" which states: "In some verses Quran, the concept of absolute science emerged in the meaning that is still common (generic)", as in QS.Al-Zumar [39]: 9; QS. Al-Baqarah [2]: 31; QS. Yusuf [12]: 76; QS. Al-Nahl [16]: 70. Malik Fajar added that the classification of science into the science of religion and non-religion (general) will cause a mistaken view that the science of non-religion is apart from Islam, and appears incompatible with the nature of the universality of Islam that claims to give mercy to the worlds (rahmatan li al-aalamin).

Although the essence of "science" is only one in the concept of Islam, the process of the birth of science is not. According to Fathurrahman (2002:327), "They are directly revealed by Allah in the form of revelation (the Qur'an), and there is knowledge acquired by man indirectly through human mind (verses of Tanziyat and Qauniyat)". In essence, the human mind is also a creation of Allah, as the Qur'an states, Allah teaches people with Kalam, teach people about anything that they do not know ".

Third, it is important to innovate in Islamic educational system, from the conventional systems to the modern system. In the Islamic education held at that time, santeri (students) usually sat cross-legged on a mat in amushalla to receive instruction from Kiyai by a method called Bandungan or sorogan. Halim's educational innovations include: the curriculum, methods, the criteria of educators, the learning process, evaluation techniques, school administration, and education management.

In an effort to improve the quality of education, K.H. Abdul Halim worked hand in hand with Jamiat Khair and Al-Ershad and leaders of education, such as: Ki Hajar Dewantara, Mohammad Syafe'i. He also used to correspond 
with Sheikh Tantawi Jauhari (author of the book of Tafsir al-Jauhar in Egypt) to ask for advice for school improvement.

Fourth, Islamic education should emphasize the education of faith, taqwa, nobility, and personality, to the students as a form of individual and social piety. Education is not just planting the concept of faith in the head, as practiced by most religious teachers today. Faith is located in the heart, not in the head. Faith is not merely knowledge unthinkable. Faith is in the heart, not in the mouth. Faith is not just in the verbal recognition, but the belief that there is no longer the slightest doubt in his heart, and seen by Allah as one who truly believes in Allah and His Messenger, as the word of Allah: "The Bedouins say, "We have believed" Say, "You have not (yet) believed; but say (instead), 'We have submitted,' for faith has not yet entered your hearts. And if you obey Allah and His Messenger, He will not deprive you from your deeds of anything. Indeed, Allah is Forgiving and Merciful" (QS. Al-Hujurat [49]:14).

Fifth, Islamic education should be able to forge independent and entrepreneur spirit to their students, so after graduating from the school one day, they will become independent. They do not depend on others, not stuck just looking for a job to the Government, but they can be self-employed according to the environmental conditions. Therefore, the students are provided with learning skills, such as: agriculture, farming, fishing, carpentry, and others. (Interview with Chalid Fadhlullah, on September, 5, 2014).

Education which is no less important in Islamic educational institutions is the educational skills to inculcate self-effort and entrepreneurship after graduation. The types of educational skills which were provided were: livestock, agriculture, farming, fishing, carpentry, handy-craft, computer science, information technology, and others. Kyai who generally have farms or fisheries, felt the benefit because his land became a santeri's laboratory without recruiting paid workers, but the santeri also felt lucky, in addition to acquiring skills, they also could enjoy the crop.

Such a holistic education combines the preparation of life and the world of work that covers the entire domain of learning, combing general and vocational education in a continuum of knowledge, values, competencies, and skills. In this case the Islamic education plays a crucial role to help people meet new learning needs and empower people to acquire the balance of life in this world and in the hereafter.

The importance of forging a spirit of entrepreneurship to students must be a serious concern of educational institutions, "because graduates of vocational schools $(S M K)$ absorbed in the formal sector of working world are only $30 \%$, and the remaining $70 \%$ work in the informal sector" (Slamet PH, 2013:15), especially graduates from high schools (SMA) and some similar schools are not prepared to work.

Sixth, it is important to give educational scouting, organization, leadership, so that students have strong mental, love their country, and are able to lead the community.

Extra lessons are derived from "Muslim Study Club" (MCS), "Hizbul Islam Padvinder Organisatie" (HIPO), "Student Council" (OSIS), "Student of PUI Community" (PPUI) which is now called the "Association of Student of PUI" (Hijar PUI), "Student Association of PUI" (Hima PUI), "Indonesian Islamic Student" (PII), and "Islamic Students Association "(HMI). According to K.H.A. Halim, even those who have higher education, ifthey do not learn to organize, usually cannot be a society, have not been called to serve and organize the community. "Science is like a lighthouse that he had not grounded and is not practiced in the community" (Interview with Chalid Fadhlullah, on September, 5, 2014).

Seventh, it must be opened, pluralistic, and egalitarian to the idea of educational innovations that are not contrary to Islamic norms. The perspective that underestimate the science and technology should not be maintained.

By the efforts of modern sciences, such as computer science and information technology, in addition to retaining the religious knowledge and the importance of faith and noble morality as PUI mandated, it is expected that madrasah Muallimat as the "cultural broker" of Islamic values, and serves as "guardian of the Islamic faith". 


\section{Education for Women in Madrasah Muallimat of PUI}

First, PUI viewed women as being entitiled to higher education as earned by men. This view has inspired K.H. Abdul Halim to establishe educational institutions for women. The way of K.H. Abdul Halim to fight against the colonzer was not by asking the community to pick the weapon, but by equipping them with education. K.H. Abdul Halim believed that education could change everything, including to repel the colonizer. Therefore, the whole society, without exception, should be educated. The concept of "education for all" that is the philosophy of western people, in fact long before that, had been affirmed by Muhammad through his saying, and K.H. Abdul Halim responded to it.

According to K.H. Abdul Halim, it is important for women to obtain higher education such as that achieved by men, to prepare them to be an educated muslimah so that they could work together in harmony with the man (husband) in educating families and communities. However, to maintain the honor of women, educational institutions where the women studied were to be separated from the men, but the level of education and the kinds of knowledge that are taught are the same between male students and female students. According to Nurmila (2009:175) in Media Pendidikan Journal:

Education is very important for women to improve the quality of themselves as well as education and welfare of their family and society. Educated women can think and act differently from lower educated women in educating and improving their family welfare. Educated women tend to be financially independent, so they could educate their children and feed them better than uneducated or lower educated women. Islam emphasizes the importance of education both for men and women. Islam also tries to elevate women's position into equal position with men

Therefore, the principle of fairness in access to education for women should be enforced, according opinion of Amin (no year: 19):

Women are no different with men. Functions of the body, feelings, mind absorptive capacity, and the nature of humanity is no different. The difference lies only in matters related to sex differences. If there men out perform women in terms of mind and body, then it does not mean that the essence of such women, but because she did not get a chance to train the mind and physical during lifetimes.

Until now, there are still many women around the world who still have limited chance to achieve higher education. It is not the fault of women and they should not be blamed if they are not motivated to reach higher education, because it is more due to the structure and culture of the society that does not give many chances for women to achieve the highest possible education.

Experts have tried to identify some of the factors that led to underdevelopment of women in education, which are caused by the high cost of schools and investment in education. So, it is often concluded that: "The higher the cost of education, the smaller the chances of women to education. The lower the family economy, the less the chance of women to achieve education. The higher the family economy, the lower the motivation to attain higher education. The higher the educational level, the fewer the number of women who were in them. The more difficultthe occupied areas of science, the fewer the number of beautiful women ".

In regard to education opportunities, Suleeman (Ihromi,1995:227- 248) states: (1) The higher the level of formal education, the more limited the number of schools are available. (2) The higher the level of education, the higherthe cost to go to school. (3) Investing in education often can not they feel because a daughter usually become a member of their husband's family after marriage. Van Bemmelen (Ihromi, 1995:175-226) found that: "Women's access to education is not as widely and as freely as men's. In addition, gender values embraced by the people who are still stereotypes, and values instilled by teachers and parent are still gender bias".

The unequal access to education between women and men may lead to injustice. According to Mosse (1996:118), "The lack of justice is due to the access, participation and control which are not 
balanced between women and men to resources and education". Suryadi (2001:68) found that: "The choice of the family with lower ecomonic status to give priority to boys for studies by the reason of cost, not only based on the mind of conservative and traditional itself, but also based on the empirical experience that level of feedback (rate of return) against women's education is lower". This is consistent with the fact that the average income of female workers empirically lower than the earnings of male workers.

The lack of education of women is very influential on access to production resources, that are more concentrated in informal employment. Women received low payment. In addition, the influence of education showed a trend: "The lower the education level, the greater the gap in the system of remuneration between workers who are educated and the less educated" (Suryadi \& Idris, 2004). Furthermore, according to Suryadi (2001:67): "Low levels of female education would cause them not to be able to play a greater role in development". Thus, the increase in the level of education and the loss of discrimination against women can provide a space for women to play a role in development and in determining the policies in the economic, social, and political life. The higher education level of women is expected to improve the quality of human resources.

According to Supiandi (2001:132): "Highly educated women are able to make families healthier and provide better quality education to their children. Highly educated women have a chance to get a better job". In contrast, women with low education are vulnerable and the economic conditions tend to be lower. Although education is not the only goal to achieve social status and high level of economy, it is undeniable that when the economic level is higher, certainly many things that can be done by women are more beneficial for themselves, their family, their community, and nation.

There are several suggestions for expanding opportunities for women's access to education:

a. Women should have extensive knowledge in education. There is no need to determinate certain role and expectation for women, because the expectation and role will influence the spirit of improvement. Now education helps to breakdown the boundaries of sexstereotyped territories. Greater flexibility in the educational schedule makes it possible for each sex to combine both work and family life.

b. Women have to get more support and priority to get high education than men at the early stage to strengthen motivation of achievement.

c. Women are not blamed and insulted if they get a failure in education, but they should continue to be supported in order to rise up and correct their mistakes. They are invited to identify the causes of failure, to formulate a plan of action to correct the problem, and they are supported morally and materially.

d. Women should be respected and strengthened when they get high achievement and are successful in education, thus giving the power to improve their performance.

e. Women should be encouraged to express their opinions clearly.

f. Do not compare the results of the achievements of women with men who would discourage women's businesses.

g. Education for women must integrate between knowledge and their feelings, so that they become not only smart intellectually, but also smart emotionally.

h. Education for women must integrate education and their life, so they can be implemented in real life and they are ready to the demand and challenge of life. New efforts to combine jobswith study also have an implication on teaching and learning and continue throughout life and not just to be segregated in four years of college.

i. Education for women should integrate the knowledge and morality as the foundation for fostering children.

j. Women should be given the opportunity to deepen the broadest social sciences, natural sciences, engineering, and others that had been owned by men (Ernest, 1976: 9-10).

k. Opportunities to learn various life skills should be provided in order to have economic independence. The new educational process may also make possible "career education" that joins studies with practical learning in a vocation. 
Second, the education in Madrasah Muallimat implements the integration of science and religion. According to K.H. Abdul Halim, it is important for women to learn a variety of sciences as learned by men. Future women projection has to become an important attention, for example by doing mapping requiring areas of science, technology, politic, religion, and economy.

The subjects in Madrasah Muallimat are: Qur'an, Tafseer, Hadith, Musthalah Hadits, Kalam, Mantiq, Akhlaq, Ubudiyah, Fiqh, Usul Fiqh, Arabic (Nahwu, Sharaf, Muthalaah, Fiqh lughah, Imla, Khat), Miqat, Al-Adyan, Faraidl, Balaghah, and Ma'any. The general subjects are: English, Regional language, Science (Physics, Chemistry, Botany), Exact Science (Literacy, Algebra, Measure), IPS (Indonesian History, World History, Islamic History, Geography, Civics, Economics, Sociology, Antropology), Life-skill, Teaching (theory and practice), and Keputrian (Hariri \&Muhafilah, 1983:12).

Third, the education in Madrasah Muallimat aims to provide prospective teachers/ educators. The students at Madrasah Muallimat are prepared to become prospective educators for the family and society. The teaching profession is considered strategic for women because it can be implemented in formal, informal, and nonformaleducational institutions, it can be held in a rural or urban, and it can also be done while educating children in their own families and the surrounding communities.

According to K.H. Abdul Halim, women should be educated because education can be beneficial to oneself, family, community, and country, in accordance with the word of wisdom: "Women are the pillar of the state". Many messages are placed on the backs of women, but all of those messages can be met and answered by giving optimal education to women. The messages are translated by PUI to establish Madrasah Muallimat, where the teaching profession is seen as a noble profession for women (Interview with Yati Rohyati \& Uum Umayah, on September,10, 2014), because teachers play very important aspects in education and the good teachers will generate good learners. According to Arifani \& Saukah (2013:77), teachers play a vital role to assure quality of education. Without qualified and standardized teachers, the educational process and objectives would be far beyond reach. Drost (2002) notes that the teacher's competence is more essential than other aspects of education. Kaplan and Owning (2007) also believe that better teaching is the key to higher student achievement.

Fourth, the education in Madrasah Muallimat emphasizes the skills of women, in addition to studying science and religion. It is intended that women are skilled at performing the work of womanhood, even though the domestic work of women is not natural, but to maintain harmonious relationships with men (fathers or husbands), women must be equipped with the skills of women, such as: cullinary art, fashion knowledge, etc.

Fifth, the education in Madrasah Muallimat emphasizes character and personality development as a Muslimah, because moral and knowledge are the basis for constructing generation in their role as educators at home together with their husbands. To foster morality and personality, students are not only taught morality and personality, and but all student behavior is also integrally considered by teachers in all subjects.

The forging of Muslimah's personality is a priority concern in Madrasah Muallimat. The green kebaya uniform, long cloth, a white hijab like an ancient javanese women had the purpose and philosophy, so that muslimah looks feminine and elegant, looks formal, but the identity as muslimah is seen by their hijab. With the fabric that restricts their movement, it is a symbol that women are expected to keep themselves. Their steps should be careful, not to be arbitrary without a clear purpose, different from the people on the streets, they can control their own lust, and they are inappropriate to walk into immoral places. But for scientific activities and skills, with long cloth uniforms, wearing kebaya and hijab, the students are still active to play drumband, joining the ceremony in the district, or doing public speaking. The body may be a little shackled, but their knowledge must be broad, so they can work together with men.

Sixth, the education in Madrasah Muallimat emphasizes the organizational and leadership education, through scouting, internal and external 
school organizations. Through the organization of education, students can learn to lead the council/ meetings, discussions, make the job desk, prepare a report on accountability, split the job desk, committees, etc. (Interview with Uum Umayah, on September, 10, 2014).

Seventh, the education in Madrasah Muallimat emphasizes mastery in Arabic language. Islamic subjects use the references in Arabic, for example: Fiqh subjects use a book of Fath alQarib for classes 1, 2, 3, and a book of Kifayat al-Ahyar for grades 4, 5, 6 subjects and a book of Bulugh al-Maram, Kalam Science uses a book of Al-Husun al Hamidiyyah, etc.

Eighth, the education in Madrasah Muallimat gives an attention to the importance of arts. The art which is a mainstay is a drumband. Until the 1980s, the drumband of Madrasah Muallimatwas the only one in Majalengka. In addition to the marching band, there is qasidah, and others are taught atthe coming of commemorations.

Ninth, education in Madrasah Muallimat is also focused on the mastery of science and technology, especially information technology and computer skills in response to globalization, because the demands of the working world are different from one or two decades ago. Global change is not only related to the qualification requirements of people to enter the job, but it can also be seen in the personal disorientation and the inaccuracy of people to occupy a jobat the same time.

Information technology will be a channel which is very wide and varied for human to learn. The shift occurred from studying through the learning process which is based on physical documents into the learning process which is based on electronic documents. The generation of learning communities is the generation of e-learning community.

The challenges of the 21 st century as a global challenge, however, requires the appropriate response of Islamic education. If the Muslims do not only want to just survive amid global competition, but also want to able to come forward, the reorientation of thinking about Islam and the education system and the institutional restructuring of Islamic education is clearly a necessity.
Perspectives that rule out science and technology cannot be maintained. Programs developed in Islamic education institutions also have to deal with science and technology. Islamic educational institutions should foster appreciation for all current and future developments, so as to produce graduates who are knowledgeable.

However, Islamic educational institutions must be careful to orient the various ideas on the present challenges, because it is not impossible that the orientation would lead to negative implications for the existence and the function of Islamic education itself. Thus, the areas of the humanities - including religion - and the social sciences remains the largest and most important part of the Islamic educational system, however, because people still trust and hope to the Islamic educational institutions for the realization of the young generation who are not only on the quality cognitive, but also affective and their psychomotor aspects.

According Hyot \& Wickwire (2001:217), there are four needs for someone after graduating from high school education: (a) planning a post-high school education which is careeroriented, (b) acquiring general skills, work skills, work adaptability, and employment, so as to follow the changing world of work as an adult, (c) emphasizing the importance of work values, (d) planning ways to occupy themselves in work as part of overall career development.

In the current era of globalization, educational institutions are required to have strong competitiveness in technology, management, leadership, and human resources, and Madrasah Muallimat has been able to respond to every idea of innovation that gives benefit to the progress and excellence of women. The demands of the globalization of the importance of superior human resources are proposed by Slamet PH (2013:20) as follows:

Advantages of human resources is the key to competitiveness, because the human resources will determine who is able to maintain the survival, development, and win in the global competition. Superior quality human resources have the properties of a creative, innovative, flexible, understanding (literacy) technology, skilled, and have 
multiple intelligences, as Trilling and Fadel (2010) suggested that educational institutions are now able to produce: "innovative, inventive, self-motivated and self-directed, creative problem solvers to confront increasingly complex global problem “.

Since 1980, the government closed schools producing future teachers, such as SPG, SGO, and the PGA, so Madrasah Muallimat becomes Madrasah Tsanawiyah and Aliyah Puteri. However, until now some elements are still retained, such as: being qualified for female students, Psychology, and Teaching is still learned in these schools, which aims to provide prospective educators in the family and society, though not licensed to provide teachers in formal schools, but alsofemale literacy classes, Arabic, and Qur'an still be featured.

Till now the society still believe that women's intelligence is lower than men's, so that pull over women to get access education. Even in families with high economic background, the opportunity to obtain education to women is still limited, more than anything else infamilies with lower economic background. Thereis also societies which still convince that women with passive cannot experiment for hours in laboratories, surveying in field, writing and discussing in rest of time. If this is conducted by women, it will result in losing of their feminine because they do nothave time to do feminine duties at home. Besides, physical weakness of women used for the activities education as wellas men will result change of graceless physical again of menfolk, and this represents deviation of women image. They think education is as physically heavy profession and needs strong muscle. Despitefully, women's role intaking care of household does need higher education, but it is enough for them to be able to read and write simply for educating childrenin early their life.

Finally, women's lack of progress through the educational system may not be the fault of women's effort if there is an unequal opportunity to learn. It may be imbalance of the culture itself, giving heavier emphasis on male rather than female, that puts women at disadvantages. The problems of educational equality between the sexes will not be solved simply by raising women's aspirations or by countering discrimination with compensatory educational programs for women, rather the educational establishment will have to reassess its heavy emphasis on scientific and occupational advancement and perhaps give greater place to the family, community, social, and institution concerns as well as Madrasah Muallimat PUI in Majalengka.

\section{CONCLUSIONS}

Based on the results, the following conclusions can be drawn.

1. Islamic Education in PUI's perspectives is that: (a) education is a very important factor for human life; (b) education should integrate science and religion, without a dichotomy; (c) improve an educational innovations; (d) Islamic education should emphasize the education of faith, devotion, noble morality and personality; (e) education must be able to forge an independent and entrepreneurial spirit; (f) it is important to give education on scouts, organization, leadership; ( $\mathrm{g}$ ) it is important to be open to the idea of renewal that is not contrary with the principle of Islam.

2. The model for women's education in Madrasah Muallimat, includes: (a) women are entitiled to higher education as that achieved by men; (b) applying the integration of science and religion; (c) the purpose of education is to prepare future teachers/educators, because the teaching profession is an honored profession for women; (d) implementing educational skills of women; (e) emphasizing the moral and personality development as a muslimah; (f) emphasizing the education of organization and leadership; (g) emphasizing mastery of Arabic language; (h) focusing on the importance of arts and sports; (i) studying the Rhetoric in theory and practice.

\section{ACKNOWLEDGEMENT}

The author would like to thank especially to K.H. Chalid Fadhlullah, Yati Rohyati, and Uum Umayah, who have provided information for this study. The author also thanks Prof. Slamet, PH, Ph.D. and Prof. Dr. Burhan Nurgiyantoro, who 
have been willing to edit and publish the results of this small study in this journal. The author wishes them all the merit and kindness rewarded by Allah. Amiin.

\section{REFERENCES}

Amin, Qasim. No year. Tahrir al-Mar'ah. Mesir: Al-Markaz Al-'Arabiyah li Al-Bahtsiwa Al-Nasyr.

Arifani, Yudhi \& Saukah, Ali. 2013. "EFL Teaching at Good Senior High Schools". Cakrawala Pendidikan. Yogyakarta: LPPMP UNY. Februari 2013, Thn XXXII, No.1.

Delors, J. 1998. Learning the Treasure Within. Australia: UNESCO Publishing.

Guba, Egon G. ed. 1990. The Paradigm Dialog. Newbury Park, London, New Delhi: SAGE publications.

Hariri, Idris. \& Muhafilah, St. 1983. Kenangkenangan Hari Ulang Tahun Madrasah Muallimat ke 22 (5 April 1961- 5 April 1983). Majalengka: Madrasah Muallimat.

Hoyt, KB \& Wickwire, PN. 2001. Knowledge Information Service Era Change in Work and Education. The Career Development Quartetly.Vol 72 No.3.

Mosse, J. C. 1996. Gender dan Pembangunan, Yogyakarta: Rifka Annisa WCC \& Pustaka Pelajar.

Nasehuddin, Toto Syatori. 2004. Sekilas tentang Sejarah PUI: Periode 1952-1976. Banten: PW PUI Banten.
Neuman, Lawrence W. 1997. Social Research Methods: Quantitative and Qualitative Approaches. Boston: Allyn and Bacon.

Nurmila, N. 2009. "Urgensi Pendidikan Bagi Perempuan dalam Islam”. Media Pendidikan: Jurnal Pendidikan Islam. Bandung: IAIN SGD. Vol XXI No August, 2.

Slamet, PH. 2013. "Pengembangan SMK Model untuk Masa Depan”. Cakrawala Pendidikan. Yogyakarta: LPPMP UNY. Februari 2013, Thn XXXII, No.1.

Suleeman, E. 1995. "Pendidikan Wanita di Indonesia". Dalam TO. Ihromi. Kajian Wanita Dalam Pembangunan. Jakarta: Yayasan Obor Indonesia.

Supiandi, Yusuf. 2001. Kebijakan dan Strategi Pengarus-utamaan Gender, Jakarta: Kantor Kementerian Pemberdayaan Perempuan.

Suradinata, Moh Musa. 1982. K.H. Abdul Halim: Sejarah dan Perjuangannya. Jakarta: IAIN Syarif Hidayatullah.

Suryadi, A, \& Idris, E. 2004. Kesetaraan Gender dalam Bidang Pendidikan, Bandung: Ganesindo.

Suryadi, A. 2001. Analisis Gender dalam Pembangunan Pendidikan. Jakarta: Bappenas \& WSPII-CIDA.

Van Bemmelen, S. 1995. "Gender dan Pembangunan: Apakah yang Baru?". Dalam TO. Ihromi. Kajian Wanita Dalam Pembangunan. Jakarta: Yayasan Obor Indonesia. 